\title{
Ecological Wisdom Values in Gedong Wareng Folklore in Pacitan
}

\author{
Latifah Mutiara Sari ${ }^{1}$, Sarwiji Suwandi ${ }^{2}$, and Sahid Teguh Widodo ${ }^{3}$ \\ \{latifahmutiarasari@student.uns.ac.id $\left.{ }^{1}\right\}$ \\ ${ }^{1}$ Master Student of Universitas Sebelas Maret, Surakarta, Indonesia \\ ${ }^{2,3}$ Universitas Sebelas Maret, Surakarta, Indonesia
}

\begin{abstract}
Environmental folklore is one of the nearly extinct oral literatures. The dominant factor is the environmental crisis that makes people not preserve folklore as a heritage that should be preserved. Technological advances make oral literature, especially environmental folklore, left behind and neglected. This research aimed to interpret the ecocritical theory of literature by expressing forms of ecological wisdom in Gedong Wareng folklore in Pacitan Regency. Ecocriticism is applied to examine folklore through data classification based on the moral principles of ecological wisdom. This research is a descriptivequalitative research with an ethnographic approach by using interview transcripts regarding Gedong Wareng folklore with the participants in Pacitan regency as data sources. The data were collected using interviews, observation, documentation, field notes, and transcription. There are three aspects in the data analysis technique, namely description, analysis, and interpretation. The research found nine data from five elements of ecological wisdom values in the Gedong Banteng Wareng folklore in Pacitan Regency. People still believe in the story and hold its ecological wisdom values, and thus, until now, they, hand in hand, keep preserving the Gedong Wareng area.

Keywords: Gedong Banteng Wareng, Folklore, Ecological Wisdom Values,
\end{abstract} Ecocriticism.

\section{INTRODUCTION}

Dealing with the current environmental crisis, (ecocritism) has a role as a negotiation medium between humans and nature related to literature. Ecocriticism is a new theory in examining the relationship between literature and the environment [1]. From some previous researches regarding ethnographic research and cultural expressions carried out, one of them shows the dangers of global warming in front of us. The human effort to improve life in the universe has become a paradox that threatens their existence. Despite their creative and critical art forms as shown in scientific research reports and public policies, short stories have indirectly aroused cultural awareness of loving the environment. This means that literature can serve as a cultural barometer and agent of change [2]. This is not much different from other researches that explain the ethics of paying attention to human relations with nature, where people are considered moral agents because of their conscience [3]. This research has the same 
object related to nature as other researchers who uncover the concept of the role of nature from the view of Malays based on its type in the Ediruslan Pe Amanriza's Dikalahkan Sang Sapurba novel[4]. Another research found contains the relationship of coastal culture between Malin Kundang and Si Tanggang folklores[5]. The other research found the form and implementation of sustainable tourism based on ecological wisdom[6]. From the previous researches, it was obvious that this research emphasized ecological wisdom values in Gedong Wareng folkrole in Pacitan Regency, which makes it different and becomes a renewal from the previous researches.

Every culture is influenced by ecosystems and local knowledge [7] showing the human response to the surrounding environment. Ecocriticism is the study of the relationship between literature and the physical environment [8]. It is similar to the research by Rai Sita Laksmi's (2018) which reveals that the form of ecological wisdom in managing Penglipuran tourism village includes wisdom in settlement management, forest management, and tourism village management. The meaning of ecological wisdom in the management of Penglipuran tourism village includes the meaning of nature preservation, socio-culture, and economy [9]. The current research has different object collection from Laksmi's. Besides, the focus of the problem is also different. This research focuses on the moral principles of ecological wisdom.

Ecocriticism can help determine, explore, and even solve ecological problems in a broader sense [10]. Environmental problems are moral problems, human behaviour problems. Thus, one way to save the environment is to be wise about the environment [11]. Ecocriticism is applied to examine folklore through data classification based on the moral principles of ecological wisdom. The moral principles of ecological wisdom values include respect for nature, responsibility towards nature, the principle of love and care, the principle of not harming the nature, and the principle of simple life and harmony with nature [11].

Literary research is closely related to the context of literary history and its socioculture[12]. One of literature is folklore. Folklore is a belief, culture, and custom passed down from generation to generation as a means of educating, controlling, and inheriting the values of life[13]. Environmental ethics is used to save the environment based on human moral responsibility [4]. Therefore, a study of environmental ethics is important.

One of the folklores found in Pacitan Regency is Gedong Wareng in Wareng Village, Punung District, Pacitan Regency. There is a myth behind the village name, such as the story about the place of hermitage and mukhso of Ki Banteng Wareng, the story about the unseen path to Gedong Wareng, and other mystical stories behind it. Therefore, various traditions and arts are kept and preserved because they describe past stories which are dedicated as the foundation of the noble values of life and should be studied more deeply.

\section{METHOD}

This research is descriptive qualitative with an ethnographic approach, which focuses on the explanation of ecological wisdom values. Ethnographic research examines identifiable social behaviour of a community [14]. Qualitative research is the research that intends to understand the phenomenon of what is experienced by the research subjects such as behaviour, perceptions, motivations, actions, etc., holistically, and by describing in the form of words and language, in a special natural context and utilizing various natural methods [15].

The research data were the excerpts of folklore obtained from the participant interview results and transcripts. The source of data was Gedong Wareng folklore from Pacitan Regency. The data were collected using interviews, observation, documentation, field notes, and 
transcription [14]. There are three aspects of ethnographic data analysis, namely description, analysis, and interpretation [16].

Data description in this research includes preparation, development, and writing processes. At the first stage, the researcher formulated objectively and focused on a series of stories. Then, the story was developed according to the literary work structure and the analysis framework was written in accordance with ecological wisdom values contained in it such as respect for nature, responsibility towards nature, the principle of love and care, the principle of not harming the nature, and the principle of simple life and harmony with nature, which were then explained in the form of an objective description. At the third stage, the researcher interpreted the data findings on the moral values of ecological wisdom in Gedong Wareng folklore in Pacitan Regency.

Data triangulations were used in this research, namely (1) source triangulation, (2) method triangulation, and (3) theory triangulation. The data triangulations were applied to achieve deeper understanding and knowledge generated by the research directly in the field and to carry out investigations so as to obtain detailed meaning and data validation [14].

\section{FINDINGS AND DISCUSSION}

Folklore is a regional literary tradition that must be preserved. The folklore is present as a past life record of its owners [17]. Therefore, folklore as oral literature must be studied, taught, and enjoyed orally [18]. The findings describe the moral principles of ecological wisdom in the Gedong Wareng folklore from Pacitan District which include respect for nature, responsibility towards nature, the principle of love and care, the principle of not harming the nature, and the principle of simple life and harmony with nature

\subsection{Respect for Nature}

Respect for nature views that humans have a moral obligation to appreciate and respect the rights of all living and non-living beings to exist, live, grow, and develop [11].

The first data is "The tree always grows well in the rainy season; there is nothing that pollutes and makes it a playground". The above excerpt explains that the tree commonly called Gedong Wareng always grows well and is never contaminated by local people as a form of respect for the nature.

The second data is "from the east to Gedong Wareng should not be built any buildings, because we believe this is the way for the unseen to go to Gedong Wareng". The excerpt explains that as a form of respect for the nature, all people of Wareng Lor believe in this and do not damage it by not making buildings in the restricted area.

The third data is "Ki Banteng Wareng was chased by the spirit of his war opponents passing the road to Gedong Wareng, and until now the road is sacred". It explains that the people of Wareng Lor believe that this is a form of respect for the nature. 


\subsection{Responsibility towards Nature}

God creates every part and object in the universe with purpose. Therefore, humans as part of nature are responsible for safeguarding them[11]

The first data is "all people of Wareng Lor carry out routine bersih desa (village cleaning) to hand-in-hand clean water sources near Gedong Wareng". The data explains that it is the responsibility of the people of Wareng Lor to do regular work at water sources near the Gedong Wareng area.

The second data is "we grow a variety of plants around the area towards Gedong Wareng and keep it as a sacred place. Menstruating women are allowed to pass through the area provided their dirty blood must not drop there". The data has sufficiently explained that the area is kept sacred, as a form of responsibility towards nature.

The third data is "every family is required to take part in routine work to maintain environmental cleanliness, especially in the Gedong Wareng area". The data indicate that the people of Wareng Lor always keep environmental cleanliness as a form of responsibility towards nature.

\subsection{Principle of Love and Care for Nature}

Love and care for nature arise due to the fact that as fellow members of the ecological community, all living things have the right to be protected, maintained, not hurt, and cared for [11].

The first data is "we build a fence around the area to Gedong Wareng as a sign that there must not be any building in the area because of several reasons". The excerpt explains that the people of Wareng Lor have a concern for the environment to be preserved.

The second data is "the vacant land is also always guarded and cleaned during the community work". The data explains that the people care about the environment that is believed to be the road of the unseen.

The third data is "we always ask for permission before conducting bersih desa ritual with the incense medium accompanied by prayers". The data shows that care for nature by is realized by asking for permission in certain ways.

\subsection{Principle of Not Harming the Nature}

The principle of not harming the nature is one manifestation of human responsibility for nature. At least, humans do not use nature unnecessarily [11].

The first data is "we don't just abandon the land empty, we use it to grow plants that would be useful, like leaves to feed our cattle". The excerpt explains that the people of Wareng Lor cultivate there, in which people are not allowed to make buildings by planting with plants which they can use to feed their animals as a manifestation of the principle of not harming the nature.

The second data is "Ki Banteng Wareng advised that we always keep our attitude in his site and we must not speak aloud for the convenience and harmony with living things and the unseen". It explains the form of the principle of not harming the nature as stated in Ki Banteng Wareng's message.

The third data is "Gedong Wareng is inside the big tree, there is a large and deep water source, but it is closed and maintained its naturalness". The data explains that the people of Wareng Lor really keep the naturalness of Gedong Wareng as a form of the principle of not harming the nature. 


\subsection{Principle of Simple Life and Harmony with Nature}

The principle of simple life and harmony with nature emphasizes the values, qualities, and ways of life. Humans should use the nature as needed and not be greedy with natural resources [11].

The first data is "we never sell the leaves we grow in the area towards Gedong Wareng, because we use them together". The data explain that the people of Wareng Lor apply the principle of simple life and harmony with nature.

The second data is "we conduct bersih desa to be grateful to the Almighty from the abundance of harvest this year, by praying and eating together at the village chief's house". It indicates that the people of Wareng Lor apply simple life and harmony with the nature by conducting bersih desa and praying to the Almighty God for the abundance of harvest in the village by praying and eating together at the village chief's house.

The third data is "we never feel disturbed; we even believe that Ki Banteng Wareng is the one who gets God's blessing to protect the people of Wareng Lor". The data shows that the people of Wareng Lor hamlet strongly believe this, so that their environment reflects the principle of simple life and harmony with nature [19].

Based on the findings, the researchers concluded that the folklore of Gedong Wareng from Pacitan Regency contained a number of values of environmental wisdom, including the moral principles contained therein. The value of environmental wisdom reflects the simplicity of the community in life together and in harmony with nature as one of respect and mutual care between nature and the surrounding community [20].

\section{CONCLUSION}

Nine data from five elements of ecological wisdom values, which until now are still preserved by the people of Wareng Lor were found, as a respect for nature. Thus, local people protect what they believe about the Gedong Wareng story by preserving what has been sacred in their environment. Apart from aforementioned above, the people of Wareng Lor also carry out routine community work as a form of responsibility towards nature like building fences for the principle of love and care for nature, using the natural environment around Gedong Wareng as a form of principle of not harming the nature, and using it together for a simple life and harmony with nature.

\section{REFERENCES}

[1] N. Dewi, "Ekokritik dalam Sastra Indonesia: Kajian Sastra yang Memihak," Adab. J. Bhs. dan Sastra, vol. 15, no. 1, p. 19, 2019.

[2] N. Dewi, "MANUSIA DAN LINGKUNGAN DALAM CERPEN INDONESIA KONTEMPORER: ANALISIS EKOKRITIK CERPEN PILIHAN KOMPAS," LITERA, vol. 14 , no. $2,2019$.

[3] A. Retnowati, E. Anantasari, M. A. Marfai, and A. Dittmann, "Environmental Ethics in Local Knowledge Responding to Climate Change: An Understanding of Seasonal Traditional Calendar PranotoMongso and its Phenology in Karst Area of GunungKidul, Yogyakarta, Indonesia," Procedia Environ. Sci., vol. 20, pp. 785-794, 2014.

[4] P. Bourdeau, "The man-nature relationship and environmental ethics," in Journal of Environmental Radioactivity, 2004, vol. 72, no. 1-2, pp. 9-15.

[5] I. Suwartini and F. Merawati, "The Coastal Culture of the People of Indonesia and Malaysia the Folklore Malin Kundang and Si Tanggang," Proc. 2nd Work. Lang. Lit. Soc. Educ., 2019. 
[6] A. A. R. S. Laksmi and A. A. G. O. Wisnumurti, "Sustainable Tourism Model Based on Environmental Wisdom in Penglipuran Tourism Village, Kubu Subdistrict, Bangli," 2019.

[7] J. Eshuis and M. Stuiver, "Learning in context through conflict and alignment: Farmers and scientists in search of sustainable agriculture," Agric. Human Values, vol. 22, no. 2, pp. 137-148, 2005.

[8] U. Le Guin, "The Carrier Bag Theory of Fiction," in The Ecocriticism Reader: Landmarks in Literary Ecology, 1996, pp. 149-154.

[9] A. A. R. S. Laksmi, A. A. G. O. Wisnumurti, and I. M. Mardika, "Environmental Wisdom in Management of Tourism Village Penglipuran in Bangli Regency," 2019.

[10] G. Garrard, "Eco-Criticism," in The Encyclopedia of Literary and Cultural Theory, 2017.

[11] A. S. Keraf, Etika Lingkungan Hidup. Jakarta: PT Kompas Media Nusantara, 2010.

[12] T. Suwondo, "Karya-Karya Fiksi Ali Akbar Navis," Al-Qalam, vol. 8, pp. 59-64, 1989.

[13] I. N. Suarka and I. W. Cika, "Pendayagunaan Folklor Sebagai Sumber Ekonomi Kreatif Di Daerah Tujuan Wisata Bali," ATAVISME, vol. 17, no. 1, p. 71, 2017.

[14] J. W. Creswell, Qualitative Inquiry \& Research Design: Choosing Among Five Approaches. 2013.

[15] L. J. Moleong, "Metodologi Penelitian Kualitatif (Edisi Revisi)," in PT. Remaja Rosda Karya, 2017.

[16] H. E. Wolcott, Writing Up Qualitative Research, 3rd ed. SAGE Publications Inc, 2009.

[17] A. Teeuw, Sastra dan Ilmu Sastra: Pengantar Teori Sastra. Jakarta: Dunia Pustaka Jaya, 1984.

[18] A. B. Lord, The Singer of Tale. New York: Atheneum, 1976.

[19] K. Saddhono and M. Rohmadi, "A Sociolinguistics Study on the Use of the Javanese Language in the Learning Process in Primary Schools in Surakarta, Central Java, Indonesia." Int. Edu. Stu., vol. 7 no.6 pp 25-30, 2014

[20] B.W. Setyawan and K. Saddhono, "Eret traditional ceremony as representation of spirit of mutual cooperation among coastal communities". Adv. Sci. Let. vol. 23 no.10, pp 9991-9992, 2017 